\title{
Formulasi dan Evaluasi Lotion Ekstrak Alpukat (Persea Americana) sebagai Pelembab Kulit
}

\author{
Benni Iskandar ${ }^{1 *}$, Santa Eni BR Sidabutar ${ }^{1}$, Leny ${ }^{2}$ \\ ${ }^{1}$ Sekolah Tinggi Ilmu Farmasi Riau, Jalan Kamboja, Simpang Baru Panam, Pekanbaru, Indonesia \\ ${ }^{2}$ Fakultas Farmasi dan Ilmu Kesehatan, Institut Kesehatan Helvetia, Medan, Indonesia \\ *E-mail: benniiskandar@stifar-riau.ac.id
}

\begin{abstract}
Avocado (Persea americana) contains a lot of vitamin A, vitamin B, vitamin $C$ and vitamin $E$ which is good to be used in skin care. One of the cosmetics for skincare is lotion, which is a liquid emulsion consisting of oil phase and water phase stabilized by emulgator. Lotion is used to protect and maintain skin moisture level. The purpose of this research was to formulate and evaluate the lotion in order to assure the physical characteristic and stability were accepted according to the Handbook of Pharmaceutical Excipients and Indonesia Pharmacopeia requirements.

Formulation were made by using these following ingredients: glyceryl monostearate, cera alba, tween 80, glycerin, liquid paraffin, benzyl alcohol, perfume, aquadest. The study used 2 variation of concentration, which is $0.5 \%$ and $1 \%$ avocado extract as active substance, besides there is variations in glyceryl monostearate (5.5\% and $5.7 \%)$, cera alba (2.7\% and $2.9 \%)$, tween 80 (3.5\% and 3.7\%), glycerin (10\% and 12\%), liquid paraffin (10\% and $12 \%)$, and benzyl alcohol (0.15\% and $0.17 \%$ ) in formulations I and II. Lotion was then tested for its physical properties, which include organoleptic test, homogeneity test, pH test, and spreadability test, lastly hedonic and irritation test were also being examined.

Based on the results of physical properties test, both lotion formulations showed a viscous texture, beige and dark beige color with a distinctive odor, homogeneous, not irritating, have a pH value in the range of 4.55-5.31 with 4.9-5.15 cm spread. In the hedonic test on 10 panelists, lotion I formulation gave the most satisfaction score and comforty from respondents. Respondent's satisfaction on the appearance comprise the texture, color, and odor. Besides, viscosity and spreadability were also marked as how comfort the lotion is when it was applied to the respondent's skin.
\end{abstract}

Keywords : Avocado, Extract, Lotion, Cosmetic, Moisturizer

\begin{abstract}
ABSTRAK
Buah alpukat (Persea Americana) mengandung vitamin A, vitamin B, vitamin C dan vitamin E yang dapat digunakan dalam perawatan kulit. Salah satu kosmetika untuk perawatan kulit adalah lotion, yang merupakan emulsi cair terdiri dari fase minyak dan fase air yang distabilkan oleh emulgator serta dapat melindungi dan menjaga kelembaban kulit. Tujuan penelitian adalah Untuk melakukan formulasi dan evaluasi sedian lotion sesuai dengan persyaratan yang ada di Handbook of Pharmaceutical Excipients dan Farmakope Indonesia (FI).

Formulasi yang digunakan menggunakan bahan-bahan sebagai berikut, gliseril monostearat, cera alba, tween 80 , parfum, gliserin, paraffin liquidim, benzil alkohol, parfum, aquadest. Penelitian menggunakan 2 formulasi lotion dengan konsentrasi ekstrak alpukat (zat aktif) sebanyak 0,5\% dan 1\% dengan variasi Gliseril Monostearat (5,5\% dan 5,7\%), Cera alba (2,7\% dan $2,9 \%$ ), Tween 80 (3,5\% dan 3,7\%), Gliserin (10\% dan 12\%), paraffin liquidim (10\% dan 12\%), dan benzil alkohol (0,15\% dan $0,17 \%$ ) pada formulasi I dan II. Sediaan lotion kemudian diuji sifat fisiknya, yang meliputi uji organoleptis, uji homogenitas, uji $\mathrm{pH}$, uji daya sebar, uji akseptabilitas dan uji iritasi.

Berdasarkan hasil pengujian sifat fisik, kedua formulasi lotion menunjukkan tekstur kental, warna krim dan kream pekat dengan bau khas, homogen, tidak mengiritasi, memiliki nilai $\mathrm{pH}$ pada kisaran 4,55-5,31 serta Daya Sebar pada pengujian 4,9$5,15 \mathrm{~cm}$. Pada uji akseptabilitas diujikan pada 10 panelis, formulasi lotion I paling memberikan kepuasan dan kenyamanan bagi responden. Kepuasan responden berkaitan dengan tekstur, warna, dan aroma terkait penampilan sediaan serta memiliki kekentalan, daya sebar yang baik sehingga memberikan rasa nyaman saat diaplikasikan pada kulit.
\end{abstract}

Kata Kunci: Alpukat, Ekstrak, Lotion, Kosmetik, Kelembaban 


\section{Pendahuluan}

Pada era globalisasi saat ini Trend back to nature tengah melanda dunia dalam meningkatkan penelitian terhadap formula kosmetika dan juga terhadap beberapa tanaman sebagai bahan aktif kosmetika. Penelitian tersebut dilakukan terhadap tanaman yang sudah digunakan secara turuntemurun maupun penelitian yang bertujuan mencari tanaman baru sebagai inovasi dan variasi bahan aktif. Peningkatan penelitian formula kosmetika juga bertujuan untuk mencari bentuk sediaan kosmetika yang tahan lama, praktis, mudah dan cepat diaplikasikan yang sudah menjadi kebutuhan manusia modern dalam kehidupan yang serba cepat atau instan [1].

Pada saat ini, sedian kosmetik merupakan bukan menjadi kebutuhan tambahan, melainkan sudah menjadi kebutuhan pokok dalam kehidupan sehari - hari demi mendapatkan dan mempertahankan kecantikan dari waktu ke waktu. Kondisi ini dimanfaatkan oleh produsen produk kecantikan. Jumlah penduduk sekitar 250 juta jiwa menjadikan Indonesia pasar yang menjanjikan bagi perusahaan kosmetik. Tanpa disadari banyak kosmetik yang banyak mengandung bahan kimia yang berbahaya, bahan tersebut antara lain, merkuri,hidroquinon, asam retrinoat, dan bahan pewarna. Pemakaian merkuri dapat menimbulkan berbagai hal antara lain perubahan warna kulit, yang kemudian bisa menyebabkan bintik-bintik hitam pada warna kulit, alergi, iritasi kulit, dan dapat menyebabkan kanker kulit pada manusia [2].

Indonesia memiliki kekayaan alam dan sumber daya alam yang sangat besar. Beberapa daerah di Indonesia terkenal dengan hasil sumber daya alamnya baik itu berasal dari pertanian, perkebunan, dan juga pertambangan. Salah satu tumbuhan yang belum terlalu maksimal di manfaatkan dalam bidang kosmetik adalah buah alpukat (Persea Americana). Buah alpukat (Persea Americana) selama ini lebih banyak dimanfaatkan sebagai jus pelepas dahaga saja, kurang mendapat perhatian untuk dimanfaatkan sebagai sediaan kosmetika yang lebih bernilai. Berdasarkan kandungan gizinya buah alpukat mengandung vitamin seperti vitamin $\mathrm{A}$, vitamin $\mathrm{B}$, vitamin $\mathrm{C}$ dan vitamin $\mathrm{E}$ [3].

Vitamin E bersifat larut dalam lipid terkonsentrasi pada situs interior hidrofobik membrane sel dan merupakan pertahanan utama terhadap oksidan yang disebabkan oleh cedera membran [3]. Vitamin E yang dikenal sebagai vitamin yang berguna untuk menghaluskan kulit. Campuran vitamin $\mathrm{E}$ dan vitamin A sangat berguna dalam perawatan kulit. Campuran vitamin $\mathrm{E}$ dan vitamin A sangat berguna dalam perawatan kulit. Kombinasi vitamin E dan vitamin A membuat kulit menjadi kenyal, menghilangkan kerut, membuat kulit terlihat muda dan segar [4].
Kandungan lain yang terdapat dalam buah alpukat adalah lemak, karbohidrat, asam folat, dan protein [1]. Buah alpukat (Persea americana) ini mempunyai potensi besar dimanfaatkan untuk kulit agar dapat menjaga kelembaban kulit, mengurangi kerut dan kekeringan, menghaluskan dan melunakkan kulit (dengan penambahan humektan) serta untuk mengantarkan zat lain seperti tabir surya yang bermanfaat untuk kulit [5].

Salah satu bentuk sedian kosmetik adalah lotion. Lotion merupakan salah satu sediaan kosmetika golongan emolien (pelembut) yang mengandung air lebih banyak. Fungsi dari lotion adalah untuk mempertahankan kelembaban kulit, membersihkan, mencegah, kehilangan air atau mempertahankan bahan aktif. Komponen-komponen yang menyusun lotion adalah pelembab, pengemulsi, bahan pengisi, pembersih, bahan aktif, pelarut, pewangi dan pengawet [6].

Lotion memilki beberapa keuntungan diantaranya mudah menyebar rata, mudah dalam penggunaannya atau mudah dioleskan, dan cara kerjanya langsung pada jaringan setempat serta efek terapi yang diharapkan lebih mudah dicapai [7].

Lotion terdiri dari pelembab, pengemulsi, pembersih, bahan aktif, pelarut, pewangi dan pengawet. Keunggulan lotion yaitu dengan kandungan air yang cukup besar bentuk sediaan lotion tersebut dapat diaplikasikan dengan mudah, daya penyebaran dan penetrasinya cukup tinggi, tidak memberikan rasa berminyak, memberikan efek sejuk, juga mudah dicuci dengan air. Lotion sudah banyak beredar di masyarakat yang mengandung berbagai manfaat salah satunya dapat melembabkan kulit [8].

Penelitian sebelumnya, pada proses ekstraksi menggunakan maserasi dengan pelarut etanol 95\% diperoleh sebesar $8,643 \%$ dan setelah dilakukan pengujian ternyata sediaan moisturizing gel yang baik serta lebih disukai adalah basis yang mengandung pati sebesar 3,2\% dan air 68\% [1]. Hasil stabilitas selama penyimpanan 56 hari dapat dinyatakan baik, walaupun nilai $\mathrm{pH}$ dan Viskositas mengalami kenaikan akibat pengaruh tiksotropik dari sediaan yang cenderung yang mengental bila didiamkan. Berdasarkan uraian diatas, Adapun alasan peneliti dan keterbaharuan dari penelitian ini yaitu Peneliti tertarik atau ingin memformulasi sedian lotion menggunakan buah Alpukat (Persea Americana) sebagai pelembab kulit yang dievaluasi sesuai dengan persyaratan sediaan lotion yang keudian diujikan terhadap persyaratan uji khusus sediaan lotion seperti yang tertera pada buku standar. Selain memanfatkan buah alpukat yang kaya akan kandungankandungan yang dibutuhkan oleh kulit untuk meningkatkan kelembaban dan Kesehatan kulit. Berikutnya latar belakang memilih sediaan lotion disbanding sediaan kosmetik lainnya dikarenakan sediaan lotion memiliki banyak kelebihan antara 
lain mengandung air lebih banyak. Fungsi dari lotion lainnya adalah untuk mempertahankan kelembaban kulit, membersihkan, mencegah, kehilangan air atau mempertahankan bahan aktif menjadi alas an pentingnya dilakukan penelitian ini.

\section{Bahan dan Metode}

\subsection{Alat}

Alat-alat yang digunakan dalan penelitian ini adalah wadah lotion, stapel, kaca arloji, lumping dan alu, timbangan analitik, sudip, cawan penguap, pH meter, gelas ukur (Pyrex®), labu ukur (Pyrex®), kertas lakmus, buret, pipet takar, pipet volume (Pyrex $\left.{ }^{\circledR}\right)$, pipet tetes $\left(\right.$ Pyrex $\left.{ }^{\circledR}\right)$, beaker glass $\left(\right.$ Pyrex $\left.{ }^{\circledR}\right)$, cawan penguap, dan Erlenmeyer (Pyrex®).

\subsection{Bahan dan Formula}

Bahan yang digunakan dalam penelitian ini adalah ekstrak buah alpukat (Persea americana) dengan kategori pharmaceutical grade dari CV. Eteris Nusantara di Yogyakarta, gliseril monostearat, cera alba, tween 80, parfum, gliserin, paraffin liquidim, benzil alkohol, parfum, aquadest.

Formula lotion ekstrak buah alpukat dapat dilihat pada Tabel 1.

Tabel 1. Formulasi basis lotion tipe minyak dalam air (M/A)

\begin{tabular}{|c|c|c|c|}
\hline \multirow{2}{*}{ Bahan } & \multicolumn{2}{|c|}{ Konsentrasi Bahan (\% b/v) } & \multirow{2}{*}{ Fungsi/Kegunaan } \\
\hline & F1 & F2 & \\
\hline Ekstrak alpukat & 0,5 & 1 & Zat aktif \\
\hline Gliseril Monostearat & 5,5 & 5,7 & Basis lotion \\
\hline Cera alba & 2,7 & 2,9 & Menstabilkan emulsi \\
\hline Tween 80 & 3,5 & 3,7 & Surfaktan \\
\hline Gliserin & 10 & 12 & Humektan \\
\hline Parafin liquidum & 10 & 12 & Lubrikan \\
\hline Benzil alcohol & 0,15 & 0,17 & Pengawet \\
\hline Parfum & Qs & Qs & Pewangi \\
\hline Aquadest ad & 100 & 100 & Pelarut \\
\hline
\end{tabular}

\subsection{Pembuatan Lotion}

Bahan bahan Fase minyak (gliseril monostearat, cera alba, tween 80, paraffin liquidum) dan fase air (gliserin, benzil alkohol, aquadest) dipisahkan. Fase minyak dan fase air dipanaskan hingga suhu $70-80{ }^{\circ} \mathrm{C}$. Setelah semuanya melebur, fase air dan fase minyak kemudian digabungkan dalam mortir panas dan diaduk perlahan - lahan hingga terbentuk basis oil in water $(\mathrm{O} / \mathrm{W})$. Kemudian ditambahkan ekstrak buah alpukat (Persea americana) serta pengaroma diaduk hingga homogen dan dimasukkan wadah lotion [9].

\subsection{Evaluasi Sediaan Lotion}

Pemeriksaan Organoleptis. Pemeriksaan organoleptis meliputi bentuk, warna dan bau [10].

Pemeriksaan Homogenitas. Satu gram basis lotion Lotion diambil pada masing-masing formula secukupnya kemudian dioleskan pada plat kaca diraba dan digosokkan, massa lotion harus menunjukkan susunan homogen yaitu tidak terasa adanya bahan padat pada kaca [6].

Pemeriksaan pH. Pemeriksaan $\mathrm{pH}$ dilakukan dengan alat $\mathrm{pH}$ meter. Alat kalibrasi dengan larutan dapar $\mathrm{pH} 4$ dan $\mathrm{pH} 7$. Kemudian elektroda dicuci dengan aquadest dan dikeringkan dengan kertas tisu. Pengukuran $\mathrm{pH}$ ditimbang sebanyak 1 gram sediaan lotion lalu diencerkan dengan $10 \mathrm{ml}$ aquades. Kemudian digunakan $\mathrm{pH}$-meter untuk mengukur $\mathrm{pH}$ sediaan lotion [10].

Pemeriksaan Daya Sebar. Lotion sebanyak 0,5 g diletakkan di tengah alat dengan diameter $15 \mathrm{~cm}$, kaca yang satu diletakkan di atasnya dibiarkan selama 1 menit. Selanjutnya diameter lotion yang menyebar diukur, ditambahkan 50 gram beban tambahan diamkan selama 1 menit, kemudian ditambahkan beban 100 gram selama 1 menit dan diukur diameter lotion yang menyebar. Dilakukan dengan replikasi 3 kali [4].

Uji Akseptabilitas. Uji akseptabilitas ini dilakukan selama 1 hari pada 10 orang panelis yang dilakukan untuk mengetahui formula mana yang paling disukai oleh 10 orang responden atau relawan sebagai lotion ekstrak buah alpukat [4].

Uji Iritasi. Pengujian dilakukan dengan uji tenpel tertutup pada kulit manusia (path test). Caranya adalah basis diambil sebanyak 0,1 gram kemudian dioleskan pada lengan bagian dalam dengan ukuran diameter $2 \mathrm{~cm}^{2}$, lalu ditutup dengan kain kassa dan plester kemudian diamati reaksi yang terjadi. Pengamatan dilakukan selama 24 jam. Diamati gejala yang timbul seperti kemerahan, gatal-gatal pada kulit. Uji iritasi ini dilakukan terhadap 6 (enam) orang panelis yang terdiri dari 3 
(tiga) laki-laki dan 3 (tiga) perempuan untuk setiap formula [11].

Analisis Data. Data yang diperoleh adalah data evaluasi lotion yang disajikan dalam bentuk table dan gambar.

\section{Hasil Dan Pembahasan}

Lotion merupakan campuran dari dua fase yang tidak bercampur, distabilkan dengan sistem emulsi dan berbentuk cairan yang dapat dituang jika ditempatkan pada suhu ruang. Lotion juga adalah sediaan yang mudah diaplikasikan dengan penyebaran yang merata [12]. Lotion memilki beberapa keuntungan diantaranya mudah menyebar rata, mudah dalam penggunaannya atau mudah dioleskan, dan cara kerjanya langsung pada jaringan setempat serta efek terapi yang diharapkan lebih mudah dicapai [7]. Kandungan air yang cukup besar bentuk sediaan lotion tersebut dapat diaplikasikan dengan mudah, daya penyebaran dan penetrasinya cukup tinggi, tidak memberikan rasa berminyak, memberikan efek sejuk, juga mudah dicuci dengan air [8].

Kestabilan suatu sediaan kosmetik merupakan hal yang harus diperhatikan. Hal ini penting mengingat suatu sediaan biasanya diproduksi dalam jumlah yang besar dan memerlukan waktu yang cukup panjang untuk sampai ke tangan konsumen. Oleh karena itu sediaan tersebut juga perlu diuji kestabilan sesuai prosedur yang telah ditentukan. Sediaan lotion yang stabil yaitu sediaan yang masih berada dalam batas yang dapat diterima selama masa periode penyimpanan dan penggunaan [11].
Pengujian karakteristik lotion yang dilakukan terhadap sediaan lotion ekstrak buah alpukat antara lain; dengan melakukan pengamatan organoleptis, homogenitas, $\mathrm{pH}$, uji iritasi, daya sebar dan uji akseptabilitas. Pengamatan organoleptis bertujuan untuk mengetahui faktor yang berpengaruh terhadap perubahan fisik kimia sediaan lotion juga berkaitan dengan kenyamanan penggunaan sediaan lotion meliputi warna yang menarik, mudah digunakan dan bau tidak tengik [9].

Pengamatan organoleptis yang dilakukan adalah pengamatan bentuk, warna, bau yang dilakukan secara visual [11] [3]. Pengamatan organoleptik menunjukkan bahwa warna dan bau dari basis dan ke dua formula selama 4 minggu tidak mengalami perubahan warna, bentuk dan aroma pada sediaan lotion, namun konsistensi dari basis. Hal ini dikarenakan selama masa penyimpanan sediaan lotion tersimpan dalam wadah yang tertutup rapat dan terlindung dari cahaya, dan menandakan bahwa pada sediaan lotion tersebut tidak terjadi perubahan kimiawi/senyawa. Hal ini membuktikan bahwa sediaan memiliki stablitas yang baik yang sesuai dengan yang tertera pada buku standar yang ditetapkan.

Berdasarkan hasil yang diperoleh pada ke-2 formulasi bentuk sediaan yang didapat berbentuk kental (semisolid), warna krem dan bau yang dihasilkan adalah berbau khas. Warna yang dihasilkan dari sediaan lotion dipengaruhi oleh konsentrasi ekstrak buah alpukat yang digunakan. Sedangkan aroma yang dihasilkan bergantung pada penambahan zat tambahan yang ditambahkan

Tabel 2. Hasil Pengamatan Organoleptis Bentuk, Warna dan Bau

\begin{tabular}{|c|c|c|}
\hline \multirow{3}{*}{ F1 } & Bentuk & Kental \\
\hline & Warna & Krim \\
\hline & Bau & Khas \\
\hline \multirow{3}{*}{ F2 } & Bentuk & Kental \\
\hline & Warna & Kream Pekat \\
\hline & $\mathrm{Bau}$ & Khas \\
\hline
\end{tabular}

Uji homogenitas merupakan perataan fase terdispersi dalam bahan pendispersi, tidak adanya agregasi partikel sekunder, distribusi yang merata dan teratur dari fase terdispersi serta penghalusan partikel primer yang besar. Pengamatan homogenitas bertujuan untuk mengetahui apakah zat aktif pada lotion sudah tercampur merata dengan basis atau tidak, sehingga zat aktif yang terkandung dalam sediaan lotion tersebar merata dan mampu menimbulkan efek terapi yang sama dan maksimal [9].

Sediaan yang homogen akan menghasilkan kualitas yang baik karena menunjukkan bahan obat terdispersi dalam bahan dasar secara merata, sehingga dalam setiap bagian sediaan mengandung obat yang jumlahnya sama. Jika bahan obat tidak terdispersi merata dalam bahan dasarnya maka obat tersebut tidak mencapai efek terapi yang diinginkan [13].

Hasil uji homogenitas menunjukan bahwa sediaan lotion tetap homogen selama waktu penyimpanan karena tidak terlihat adanya butiran - butiran kasar dan terlihat transparan pada kaca dan permukaannya halus merata. Hal ini dikarenakan pada formulasi sediaan lotion zat aktif dan zat tambahan lainnya tercampur sempurna sehingga didapat sediaan gel yang homogen. Formula 1 dan Formula 2 tidak mengalami perubahan homogenitas selama 28 hari penyimpanan sehingga dapat dikatakan sediaan lotion stabil dalam hal homogenitasnya. 
Tabel 3. Homogenitas lotion Ekstrak Buah Alpukat

\begin{tabular}{ccccc}
\hline Formulasi & $\mathbf{1}$ & $\mathbf{2}$ & $\mathbf{3}$ & $\mathbf{4}$ \\
\hline F1 & Homogen & Homogen & Homogen & Homogen \\
F2 & Homogen & Homogen & Homogen & Homogen \\
\hline
\end{tabular}

Tabel 4. Hasil Pengukuran $\mathrm{pH}$ Sediaan Lotion Ekstrak Buah Alpukat

\begin{tabular}{ccccc}
\hline Formulasi & \multicolumn{3}{c}{ pH Sediaan Minggu Ke } \\
\cline { 2 - 5 } & 1 & 2 & 3 & 4 \\
F1 & 5,26 & 4,84 & 4,85 & 4,83 \\
F2 & 5,31 & 4,62 & 4,61 & 4,55 \\
\hline
\end{tabular}

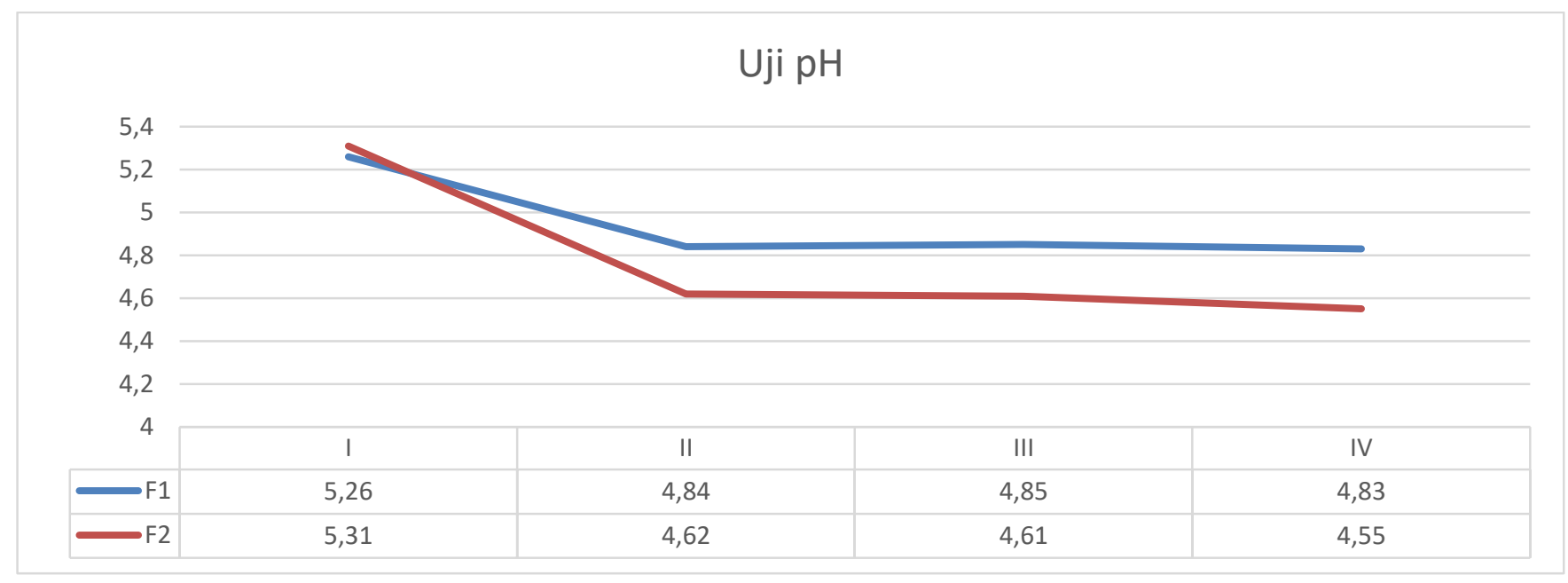

Gambar 1. Grafik pH Sediaan Lotion Ekstrak Buah Alpukat

Uji $\mathrm{pH}$ bertujuan untuk mengetahui keamanan sediian lotion pada saat penggunaan agar tidak mengiritasi kulit, stabilitas sediaan, dan efektifitasnya [14]. Hasil pengamatan $\mathrm{pH}$ dari masing-masing formulasi sediaan gel selama penyimpanan 4 minggu pada suhu $25^{\circ} \mathrm{C}$, dikatakan $\mathrm{pH}$ sediaan relatif stabil pada penyimpanan dan masih berada dalam rentang $\mathrm{pH}$ normal kulit yaitu 4,5-6,5 nilai penyimpanan [7]. Sedangkan menurut SNI nomor 16-43991996 yaitu 4,5-8,0 untuk sediaan topikal. Hasil pH yang diperoleh berada pada rentang 4,5-6,8. Perbedaan nilai $\mathrm{pH}$ yang diperoleh dapat disebabkan karena penambahan konsentrasi emulgator yang berbeda. Namun, perbedaan nilai $\mathrm{pH}$ tidak berpengaruh karena sudah sesuai dengan rentang $\mathrm{pH}$ yang dipersyaratkan (mendekati $\mathrm{pH}$ normal pada kulit). Hasil pengukuran $\mathrm{pH}$ selama 28 hari menunjukkan bahwa kedua fomula lotion yang dibuat mengalami perubahan $\mathrm{pH}$, tapi dalam rentang normal. Dapat disimpulkan bahwa variasi kadar ekstrak buah alpukat mempengaruhi kestabilan $\mathrm{pH}$.

Sediaan topikal dengan nilai $\mathrm{pH}$ yang terlalu asam dapat mengiritasi kulit sedangkan bila nilai $\mathrm{pH}$ terlalu basa dapat membuat kulit kering dan bersisik [7]. Bila pH sediaan berada di luar interval pH kulit dikhawatirkan akan menyebabkan kulit bersisik atau bahkan terjadi iritasi sedangkan bila berada di atas pH kulit dapat menyebabkan kulit terasa licin, cepat kering, serta dapat mempengaruhi elastisitas kulit. Uji pH dilakukan dengan menggunakan kertas $\mathrm{pH}$.

Uji iritasi dilakukan terhadap sediaan lotion yang dibuat dari buah alpukat (Persea americana) dengan maksud untuk memastikan bahwa lotion yang dibuat tidak menimbulkan iritasi pada kulit. Teknik yang digunakan pada uji iritasi ini adalah uji temple terbuka (Patch Test) pada lengan bawah bagian dalam terhadap 10 orang sukarelawan. Uji tempel terbuka dilakukan dengan mengoleskan sediaan yang dibuat pada lokasi lekatan dengan luas tertentu $(2,5 \times 2,5 \mathrm{~cm})$, dibiarkan terbuka dan diamati apa yang terjadi. Uji ini dilakukan sebanyak 1x 24 jam untuk sediaan dengan konsentrasi ekstrak buah alpukat sebesar 0,5\% dan 1,0\%, reaksi yang terjadi diamati. Reaksi iritasi positif ditandai oleh adanya kemerahan, gatal-gatal, atau bengkak pada kulit lengan bawah bagian dalam yang diberi perlakuan. Hasil 
Volume 6 (1) 2021 p14-21

pengamatan menunujukkan tidak adanya reaksi alergi yang ditimbulkan oleh sediaan lotion ekstrak buah alpukat sebesar $0,5 \%$ dan $1,0 \%$. Uji akseptabilitas meliputi warna, bau, tekstur, dan kekentalan pada sediaan. Berdasarkan hasil uji panelis, peneliti ingin melihat manakah dari 2 formula yang lebih di sukai panelis. Uji panelis melibatkan 10 orang sukarelawan yang menyetujui untuk berpartisipasi dalam pengujian ini.

Tabel 5. Data Uji Iritasi. Ket: Iritasi (I), Tidak Iritasi (TI)

\section{Formulasi}

F1

F2

TI

TI

\section{Pengamatan Iritasi Responden Ke-}

$2 \quad 3 \quad 4$

TI

TI

TI
TI

TI

Tabel 6. Data Uji Akseptabilitas/Kesukaan

\begin{tabular}{|c|c|c|c|c|c|c|c|c|}
\hline \multirow[t]{2}{*}{ Parameter } & \multicolumn{2}{|c|}{ Warna } & \multicolumn{2}{|c|}{ Aroma } & \multicolumn{2}{|c|}{ Bentuk } & \multicolumn{2}{|c|}{ Kekentalan } \\
\hline & $\mathrm{F} 1$ & $\mathrm{~F} 2$ & F1 & $\mathrm{F} 2$ & $\mathrm{~F} 1$ & $\mathrm{~F} 2$ & F1 & $\mathrm{F} 2$ \\
\hline sangat suka & $30 \%$ & $10 \%$ & $80 \%$ & $30 \%$ & $90 \%$ & $10 \%$ & $90 \%$ & $40 \%$ \\
\hline Suka & $70 \%$ & 0 & $10 \%$ & 0 & $10 \%$ & 0 & $10 \%$ & 0 \\
\hline Kurang suka & 0 & $60 \%$ & $10 \%$ & $30 \%$ & 0 & $70 \%$ & 0 & $30 \%$ \\
\hline Tidak suka & 0 & $30 \%$ & 0 & $40 \%$ & 0 & $20 \%$ & 0 & $30 \%$ \\
\hline
\end{tabular}

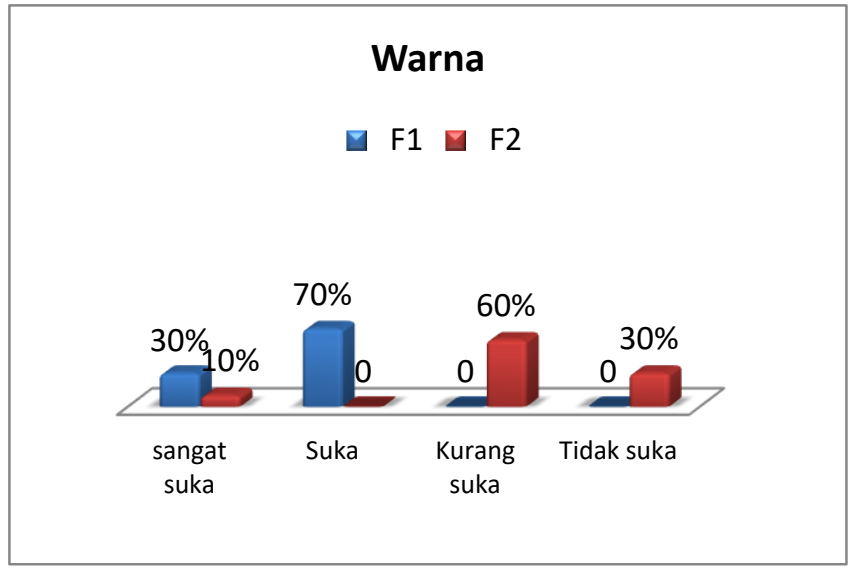

Gambar 2. Diagram Uji Akseptabilitas Warna

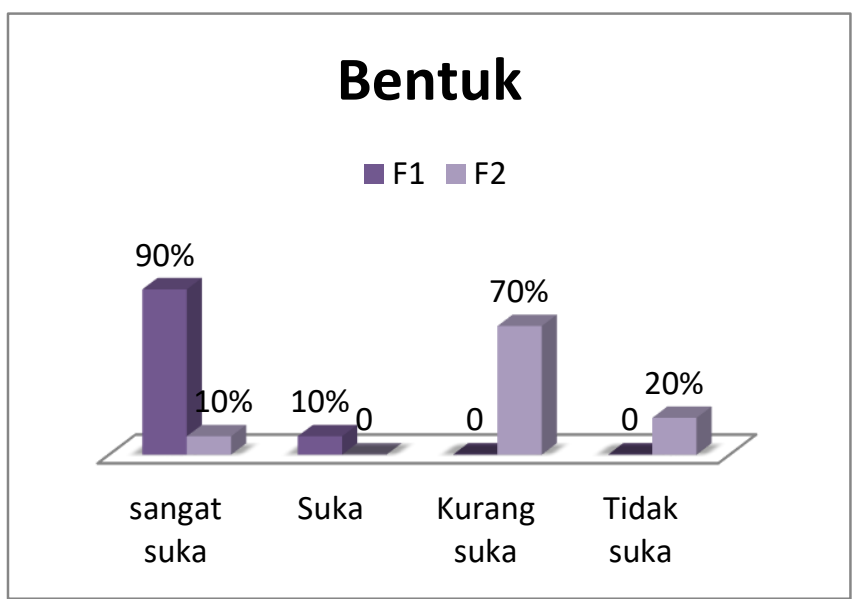

Gambar 4. Diagram Uji Akseptabilitas Bentuk

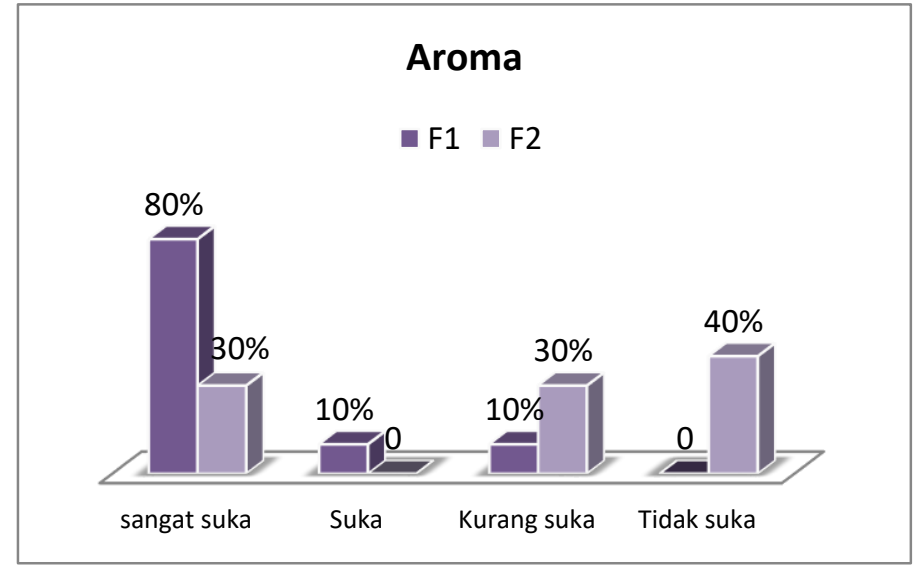

Gambar 3. Diagram Uji Akseptabilitas Aroma

\section{Kekentalan}

- F1 F2

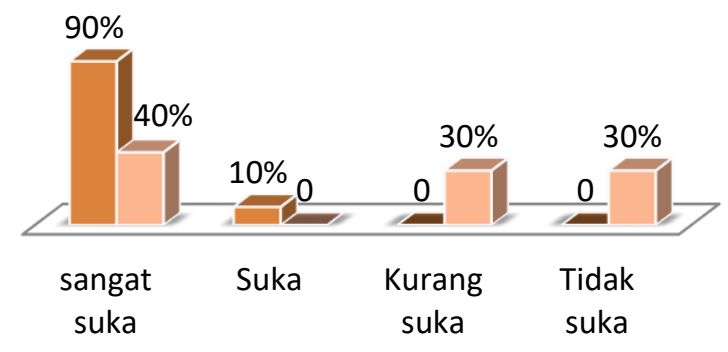

Gambar 5. Diagram Uji Akseptabilitas Kekentalan 
Panelis akan diberi kertas yang berisikan informasi mengenai apa yang akan dinilai dari sediaan lotion, F1 yang paling disukai dari panelis dibandingkan dengan F2. Hal ini dikarenakan pada formula 1 mudah dioles, warna krem lembut, selain itu panelis juga menyukai bau dari sediaan pada F1 ini yang tidak menyengat. Dan formula 1 memiliki viskositas yang sesuai dan tidak lengket, tidak terlalu encer dan tidak terlalu kental sehingga nyaman digunakan.

Dari hasil pengujian terhadap responden bahwa kebanyakan responden memlih formula 1. Hal ini Karena Uji akseptabilitas ini dilakukan selama 1 hari. Pada 10 orang panelis yang dilakukan untuk mengetahui formula mana yang paling disukai oleh relawan sebagai lotion ekstrak buah alpukat. Adapun hasil uji pada relawan terhadap lotion buah alpukat dapat dilihat pada Tabel 6 .

Pengujian daya sebar sediaan lotion ekstrak etanol kulit batang faloak dilakukan mulai dari minggu ke-0 sampai minggu ke-4. Uji daya sebar bertujuan untuk mengetahui zat aktif yang dapat terdispersi merata atau tidak pada kulit sehingga dapat menimbulkan efek terapi yang merata dan maksimal atau tidak [9]. Daya sebar berhubungan dengan penyebaran lotion pada kulit dan untuk kedua formula lotion pada penyimpanannya menunjukan sangat mudah menyebar, karena pertambahan luas yang diberikan memenuhi syarat yaitu $5-7 \mathrm{~cm}$.

Hasil yang diperoleh berkisar pada 5,0 cm $-5,15 \mathrm{~cm}$ (selengkapnya dapat dilihat pada table 3 ). Hasil pengukuran daya sebar lotion buah alpukat menunjukkan hasil yang cukup stabil selama penyimpanan 28 hari. Formula 1 memiliki daya sebar sebesar 5,00 - 5,05 cm dan Formula 2 sebesar 5,00 - 5, $15 \mathrm{~cm}$. Daya sebar yang baik yaitu 5-7 cm [15].

Berdasarkan data yang diperoleh sediaan lotion yang dibuat memiliki kemampuan menyebar yang baik dimana luas sediaan uji sebanding dengan penambahan beban. Hal ini disebabkan karena lotion adalah sediaan kosmetika yang berupa emulsi yang mengandung air lebih banyak.

Tabel 7. Data Uji Daya Sebar

\begin{tabular}{|c|c|c|c|c|}
\hline Formulasi & & Minggu Ke-1 & Minggu Ke-4 & Minggu Ke-8 \\
\hline \multirow[b]{2}{*}{ F1 } & 50 gram & $5 \mathrm{~cm}$ & $5 \mathrm{~cm}$ & $4,9 \mathrm{~cm}$ \\
\hline & 100 gram & $5,1 \mathrm{~cm}$ & $5,1 \mathrm{~cm}$ & $5 \mathrm{~cm}$ \\
\hline \multirow{4}{*}{$\mathrm{F} 2$} & Rata-Rata & $5,05 \mathrm{~cm}$ & $5 \mathrm{~cm}$ & $5 \mathrm{~cm}$ \\
\hline & 50 gram & $5,1 \mathrm{~cm}$ & $5,1 \mathrm{~cm}$ & $5 \mathrm{~cm}$ \\
\hline & 100 gram & $5,2 \mathrm{~cm}$ & $5 \mathrm{~cm}$ & $5 \mathrm{~cm}$ \\
\hline & Rata-Rata & $5,15 \mathrm{~cm}$ & $5 \mathrm{~cm}$ & $5 \mathrm{~cm}$ \\
\hline
\end{tabular}

Faktor yang mempengaruhi diameter daya sebar suatu sediaan adalah jumlah ekstrak yang digunakan setiap masing masing formula. Hal ini berdasarkan pada kenyataan bahwa semakin rendah konsistensi sediaan lotion dengan waktu lekat yang lebih rendah maka dapat membuat lotion semakin mudah menyebar [15]. Semakin meningkat konsentrasi ekstrak, daya sebar sediaan semakin meningkat, hal ini disebabkan karena semakin menurunnya viskositas sediaan. Nilai daya sebar berbanding terbalik dengan viskositas, dimana semakin besar daya sebar maka semakin kecil nilai viskositas [16]. Daya sebar pada sediaan dilakukan untuk mengetahui kemampuan menyebar lotion saat diaplikasikan ke kulit. Adanya penambahan beban menyimpulkan diameter penyebarannya juga juga semakin besar sehingga semakin besar juga luas penyebarannya.

\section{Kesimpulan}

Lotion ekstrak buah alpukat (Persea americana) 0,5\% dan $1,0 \%$ telah memenuhi karakteristik yang telah ditetapkan antara lain meliputi organoleptis, homogenitas, daya sebar, $\mathrm{pH}$ dan iritasi

Serta dari hasil uji kesukaan (akseptabilitas) sediaan menggunakan formulasi 1 dengan konsentrasi buah alpukat (Persea americana) 0,5\% manjadi formula yang paling disukai oleh panelis.

\section{Daftar Pustaka}

[1] Wardhana, W., Sopyan, I.,dan Wathoni, N.2009. Pemanfaatan Ekstrak Buah Alpukat Menjadi Sediaan Moisturizing Gel Dengan Menggunakan Teknologi Thixogel.Skripsi. Bandung: Universitas Padjadjaran.

[2] Pravitasari, D. N. 2010. Efek Samping Kosmetik Dan Penanganannya. Jurnal Kedokteran Dan Kesehatan, 6 (2).

[3] Iskandar, B., Karsono., Silalahi, J. (2016). Preparation of Spray Nanoemulsion and Cream Containing Vitamin E as Anti-aging Product Tested in Vitro and in Vivo Method. International Journal PharmaTech Research. 9(6): 307-308.

[4] Iskandar, B., Putri, DD., Firmansyah, F., Frimayanti, N., Agustini, TT. (2019). Evaluasi sifat fisik dan uji kelembaban ssediaan losion yang dijual secara online-shop. Jurnal dunia farmasi, 4 (1), 8-16. 
[5] Draelos. 2006. Ingredients Can Hide Flaws, Add Colour, Protect Skin Against the Sun and More. Journal of the American Academy of Dermatology. 18(4): 597-607.

[6] Mohiudin, AK. (2019). Skin care : Formulation and use. American journal of dermatological research and reviews. 2 (8).

[7] Tranggono, R. I. dan Latifah, F. 2018. Buku Pegangan Ilmu Pengetahuan Kosmetik edisi kedua. Jakarta: Gramedia Pustaka Utama.

[8] Aulton, M. 2007. Aulton's Pharmaceutics: The Design and Manufacture of Medicines. London: Elsevier.

[9] Amatullah, L., Cahyaningrum, T., dan Fidyaningsih, A. 2017.Efektifitas Antioksidan Pada Formulasi Skin Lotion Ekstrak Mesocarp Buah Lontar (Borassus Flabellifer) Terhadap Tikus Putih Jantan Galur Wistar Secara InSitu.Skripsi. Surakarta: Akademi Farmasi Nasional Surakarta.

[10] Megantara, I. N. A. P., Megayanti, K., Wirayanti, R., Esa, I. B. D., Wijayanti, N. P. D., Yustiantara, P.S. 2017. Formulasi Lotion Ekstrak Buah Raspberry (Rubus rosifolius) dengan Variasi Konsentrasi Trietanolamin sebagai Emulgator serta Uji Hedonik terhadap Lotion. Jurnal Farmasi Udayana. 6(1):1-5.

[11] Dewi, T. S. P. 2014. Kualitas Lotion Ekstrak Kulit Buah Manggis. Skripsi.Yogyakarta: Universitas Atma Jaya.

[12] Mirnawaty, S..J., 2012. Uji Efektivitas Ekstrak Kulit Langsat (Lansium domesticum) Sebagai Anti Nyamuk Elektrik Terhadap Nyamuk Aedes Aegypti.Skripsi. Palu: Universitas Tadulako.

[13] Ulaen, Selfie P.J., Banne, Yos Suatan \& Ririn A,. 2012. Pembuatan Salep AntiJerawat dari Ekstrak Rimpang Temulawak (Curcuma xanthorrhiza Roxb.). Jurnal Ilmiah Farmasi. 3(2): 45-49.

[14] Fajriyah, U. 2011. Formulasi lotion herba tali putri (Cuscuta australis R.br) dan aktivitas antioksidan secara in vitro.Skripsi. Purwokerto: Fakultas Farmasi, Universitas Muhammadiyah Purwokerto.

[15] Garg, A., Aggarwal, D., Garg, S., dan Sigla, A. K., 2002, Spreading of Semisolid Formulation: An Update, Pharmaceutical Technology, 84-102. 